\title{
Role of $I L-8$ gene polymorphisms in glioma development in a Chinese population
}

\author{
J.W. Fu, K.W. Wang and S.T. Qi \\ Department of Neurosurgery, Nanfang Hospital, Southern Medical University, \\ Guangzhou, China \\ Corresponding author: S.T. Qi \\ E-mail: qisongtt@163.com \\ Genet. Mol. Res. 15 (3): gmr. 15038127 \\ Received December 17, 2015 \\ Accepted January 15, 2016 \\ Published August 18, 2016 \\ DOI http://dx.doi.org/10.4238/gmr.15038127 \\ Copyright (C) 2016 The Authors. This is an open-access article distributed under the terms of \\ the Creative Commons Attribution ShareAlike (CC BY-SA) 4.0 License.
}

\begin{abstract}
This case-control study aimed to investigate the role of $-251 \mathrm{~T}>\mathrm{A}(\mathrm{rs} 4073)$ and $-781 \mathrm{C}>\mathrm{T}(\mathrm{rs} 2227306)$ polymorphisms in the interleukin-8 $(I L-8)$ gene in the development of glioma in a Chinese population. One hundred and twenty-seven glioma patients and 284 healthy control subjects were recruited to this study between February 2013 and December 2014. The $I L-8-251 \mathrm{~T}>\mathrm{A}$ (rs4073) and $-781 \mathrm{C}>\mathrm{T}$ (rs2227306) polymorphisms were genotyped by polymerase chain reaction coupled with restriction fragment length polymorphism. The patients and control subjects were comparable by gender $\left(\chi^{2}=\right.$ $1.24, \mathrm{P}=0.27)$, tobacco smoking status $\left(\chi^{2}=0.80, \mathrm{P}=0.37\right)$, alcohol consumption status $\left(\chi^{2}=0.97, \mathrm{P}=0.32\right)$, and family history of cancer $\left(\chi^{2}=1.54, \mathrm{P}=0.22\right)$. The age of glioma patients was statistically lower than that of control subjects $(t=2.87, \mathrm{P}=0.002)$. The chisquare test revealed the lack of any statistically significant differences in the genotype distributions of $I L-8 \mathrm{rs} 4073\left(\chi^{2}=0.89, \mathrm{P}=0.64\right)$ and rs $2227306\left(\chi^{2}=2.58, \mathrm{P}=0.28\right)$ between the glioma patients and control subjects. Unconditional logistic regression analysis revealed that the
\end{abstract}


$I L-8$ rs4073 and rs2227306 gene polymorphisms did not contribute to the development of glioma. In conclusion, we determined that there is a lack of evidence suggesting a significant association between the $I L-8$ rs4073 and rs2227306 gene polymorphisms and the development of glioma in a Chinese population.

Key words: IL-8; Polymorphism; Glioma; Chinese population

\section{INTRODUCTION}

Glioma accounts for more than $70 \%$ of all brain tumors (Wen and Kesari, 2008). Tumors in the central nervous system have been estimated to be the fifth and second most common type of tumors affecting adults and children, respectively. Glioma has a poor prognosis and is correlated with high mortality, despite the development of advanced treatment strategies for this disease (Ohgaki and Kleihues, 2005; Jakola et al., 2012). Moreover, the etiology of this disease remains unclear, exposure to high doses of ionizing radiation contributes to glioma development (Schwartzbaum et al., 2006). Several studies conducted so far have shown that genetic factors such as XRCC1,CCDC26, CASP8, D302H, LIG4, XRCC4, PTGS2, and $T G F-\beta 1$ play a critical role in the development of glioma (Li et al., 2015; Cacina et al., 2015; Cui, 2015; Lin et al., 2015; Lu et al., 2015; Su et al., 2015; Vieira de Castro et al., 2015).

Previous studies have indicated that IL-8 is correlated with many autoimmune diseases and infectious diseases, as well as tumors (Xie, 2001; Brat et al., 2005). Approximately 1\% of the population shows genetic variations that determine the susceptibility of an individual to cancers (Liu et al., 2006). IL-8 is encoded by the $I L-8$ gene, which is located on chromosome 4q13-21 and is composed of four exons, three introns, and the proximal promoter region (Mukaida et al., 1989). Here, we conducted a case-control study to investigate the role of $I L-8$ $-251 \mathrm{~T}>\mathrm{A}(\mathrm{rs} 4073)$ and $-781 \mathrm{C}>\mathrm{T}(\mathrm{rs} 2227306)$ gene polymorphisms in the development of glioma in a Chinese population.

\section{MATERIAL AND METHODS}

\section{Patients}

We recruited 127 glioma patients and 284 healthy controls from Nanfang Hospital between February 2013 and December 2014. All patients were diagnosed by pathological examinations conducted independently by two pathologists. The control subjects were recruited from among individuals who underwent a regular health examination at the hospital. All control subjects were confirmed to be free of glioma or any central nervous system tumors on performing computed tomography or magnetic resonance imaging examination. Study subjects with a history of cancer (or with recurrent cancer), or with serious kidney and liver diseases were excluded from this study.

The demographic characteristics of the glioma patients and control subjects, including the age, gender, and tobacco smoking and alcohol consumption status, and the family history of cancer, were collected through a questionnaire. Data regarding the clinical characteristics of glioma, including histological type (high and low grades) and WHO tumor stage (I-II and III-IV stages), were collected from the patient medical records.

Genetics and Molecular Research 15 (3): gmr.15038127 
Signed informed consent forms were obtained from the patients and controls. The study was approved by the Ethics Committee of the Nanfang Hospital.

\section{Genotyping methods}

Genomic DNA was extracted using the TIANamp Blood DNA Kit (Tiangen, Beijing, China) according to the manufacturer instructions. The $I L-8-251 \mathrm{~T}>\mathrm{A}$ (rs4073) and -781 $\mathrm{C}>\mathrm{T}$ (rs2227306) polymorphisms were genotyped by polymerase chain reaction coupled with restriction fragment length polymorphism (PCR-RFLP). The PCR primers are summarized in Table 1. The $I L-8$ rs4073 and rs2227306 were digested using $\mathrm{MfeI}$ and $B c l$ I restriction enzymes, respectively. The cycling conditions were set as follows: initial denaturation at $95^{\circ} \mathrm{C}$ for $10 \mathrm{~min} ; 35$ cycles of denaturation at $95^{\circ} \mathrm{C}$ for $30 \mathrm{~s}$, annealing at $62^{\circ} \mathrm{C}$ for $30 \mathrm{~s}$, and extension at $72^{\circ} \mathrm{C}$ for $30 \mathrm{~s}$; and a final extension at $72^{\circ} \mathrm{C}$ for $10 \mathrm{~min}$.

Table 1. Primers used to genotype the $I L-8$ rs4073 and rs2227306 polymorphisms.

\begin{tabular}{l|l|l}
\hline Gene & SNP & Primers (5'-3') \\
\hline$I L-8-251 \mathrm{~T}>\mathrm{A}$ & rs4073 & $\begin{array}{l}\text { Forward: TAAAATACTGAAGCTCCACAATGG } \\
\text { Reverse: ATCTTGTTCTAACACCTGCCACTCT }\end{array}$ \\
\hline$I L-8-781 \mathrm{C}>\mathrm{T}$ & $\begin{array}{l}\text { Forward: AAGGGTCAGTGTGGTATCACAGAG } \\
\text { Reverse: GTCAGTCAGTCATAACTGACAAGC }\end{array}$ \\
\hline
\end{tabular}

\section{Statistical analysis}

The differences in demographic and lifestyle characteristics between groups were analyzed using the chi-square test or the Student $t$-test. Genotypes of the $I L-8$ rs 4073 and rs2227306 from the Hardy-Weinberg equilibrium (HWE) were analyzed using the Pearson chi-square test. The association between gene polymorphisms and development of glioma was determined using logistic regression analysis; the results are reported as odds ratios (OR) and their $95 \%$ confidence intervals (CIs). A P value $<0.05$ was considered to be a significant difference.

\section{RESULTS}

The baseline and clinical data of study subjects are summarized in Table 2 . The patients and control subjects were comparable by gender $\left(\chi^{2}=1.24, \mathrm{P}=0.27\right)$, tobacco smoking status $\left(\chi^{2}=0.80, \mathrm{P}=0.37\right)$, alcohol consumption status $\left(\chi^{2}=0.97, \mathrm{P}=0.32\right)$, and family history of cancer $\left(\chi^{2}=1.54, \mathrm{P}=0.22\right)$. The age of glioma patients was lower compared to that of control subjects $(t=2.87, \mathrm{P}=0.002)$. Of the 127 glioma patients, $40(31.50 \%)$ showed a high-grade tumor (histological type), while $87(68.50 \%)$ patients showed low-grade tumor; 52 patients (40.94\%) were at tumor stages I-II, and $75(59.06 \%)$ displayed tumor stages III-IV.

The genotype distribution and their association with glioma risk are shown in Table 3. The chi-square test showed no statistically significant differences in the genotype distributions of $I L-8 \mathrm{rs} 4073\left(\chi^{2}=0.89, \mathrm{P}=0.64\right)$ and $\mathrm{rs} 2227306\left(\chi^{2}=2.58, \mathrm{P}=0.28\right)$ between glioma patients and control subjects. The goodness-of-fit $\chi^{2}$ test revealed that the genotype frequencies of $I L-8$ rs4073 and rs2227306 did not deviate from the HWE ( $\mathrm{P}$ values $=0.25$ and 0.79 , respectively). Unconditional logistic regression analysis revealed that the $I L-8$ rs 4073 and rs 2227306 gene 
polymorphisms did not contribute to the development of glioma (Table 3). Moreover, the allele frequencies of $I L-8$ rs 4073 and rs2227306 were not significantly associated with glioma risk.

Table 2. Demographic characteristics of glioma patients and control subjects.

\begin{tabular}{|c|c|c|c|c|c|c|}
\hline Variables & $\begin{array}{l}\text { Patients } \\
(\mathrm{N}=127)\end{array}$ & $\%$ & $\begin{array}{c}\text { Controls } \\
(\mathrm{N}=284)\end{array}$ & $\%$ & $\begin{array}{c}\text { Chi-square test or } \\
\text { Student } t \text {-test }\end{array}$ & P value \\
\hline Age (years) & $41.40 \pm 17.32$ & & $46.52 \pm 16.42$ & & 2.87 & 0.002 \\
\hline \multicolumn{7}{|l|}{ Gender } \\
\hline Male & 79 & 62.20 & 160 & 56.34 & & \\
\hline Female & 48 & 37.80 & 124 & 43.66 & 1.24 & 0.27 \\
\hline \multicolumn{7}{|c|}{ Tobacco smoking } \\
\hline Never & 57 & 44.88 & 141 & 49.65 & & \\
\hline Ever & 70 & 55.12 & 143 & 50.35 & 0.80 & 0.37 \\
\hline \multicolumn{7}{|c|}{ Alcohol consumption } \\
\hline Never & 97 & 76.38 & 229 & 80.63 & & \\
\hline Ever & 30 & 23.62 & 55 & 19.37 & 0.97 & 0.32 \\
\hline \multicolumn{7}{|c|}{ Family history of cancer } \\
\hline No & 114 & 89.76 & 265 & 93.31 & & \\
\hline Yes & 13 & 10.24 & 19 & 6.69 & 1.54 & 0.22 \\
\hline \multicolumn{7}{|c|}{ Histology type } \\
\hline High grade & 40 & 31.50 & & & & \\
\hline Low grade & 87 & 68.50 & & & & \\
\hline \multicolumn{7}{|c|}{ WHO tumor stage } \\
\hline I-II & 52 & 40.94 & & & & \\
\hline III-IV & 75 & 59.06 & & & & \\
\hline
\end{tabular}

Table 3. Association between $I L-8$ rs4073 and rs2227306 gene polymorphisms and development of glioma.

\begin{tabular}{|c|c|c|c|c|c|c|c|c|c|}
\hline$I L-8$ & $\begin{array}{c}\text { Patients } \\
(\mathrm{N}=127)\end{array}$ & $\%$ & $\begin{array}{c}\text { Controls } \\
(\mathrm{N}=284)\end{array}$ & $\%$ & $\begin{array}{c}\text { Chi-square } \\
\text { test }\end{array}$ & $P$ value & $\begin{array}{l}\text { P for } \\
\text { HWE }\end{array}$ & OR $(95 \% \mathrm{CI})$ & P value \\
\hline \multicolumn{10}{|c|}{ rs 4073} \\
\hline TT & 32 & 25.20 & 83 & 29.23 & & & & 1.0 (Ref.) & - \\
\hline TA & 60 & 47.24 & 132 & 46.48 & & & & $1.18(0.69-2.04)$ & 0.53 \\
\hline AA & 35 & 27.56 & 69 & 24.30 & 0.89 & 0.64 & 0.25 & $1.32(0.71-2.44)$ & 0.35 \\
\hline \multicolumn{10}{|c|}{ Allele } \\
\hline $\mathrm{T}$ & 124 & 48.82 & 298 & 52.74 & & & & 1.0 (Ref.) & - \\
\hline $\mathrm{A}$ & 130 & 51.18 & 270 & 47.79 & 0.93 & 0.33 & & $1.16(0.85-1.57)$ & 0.33 \\
\hline \multicolumn{10}{|c|}{ rs2227306 } \\
\hline $\mathrm{CC}$ & 54 & 42.52 & 139 & 48.94 & & & & 1.0 (Ref.) & - \\
\hline CT & 55 & 43.31 & 118 & 41.55 & & & & $1.20(0.75-1.93)$ & 0.43 \\
\hline TT & 18 & 14.17 & 27 & 9.51 & 2.58 & 0.28 & 0.79 & $1.72(0.82-3.53)$ & 0.11 \\
\hline \multicolumn{10}{|c|}{ Allele } \\
\hline $\mathrm{C}$ & 163 & 64.17 & 396 & 69.72 & & & & 1.0 (Ref.) & - \\
\hline $\mathrm{T}$ & 91 & 35.83 & 172 & 30.28 & 2.48 & 0.12 & & $1.29(0.93-1.78)$ & 0.12 \\
\hline
\end{tabular}

\section{DISCUSSION}

Here, we performed a study to assess the association between $I L-8$ rs4073 and rs2227306 gene polymorphisms and glioma risk in a Chinese population; however, we observed no significant association between the $I L-8$ rs4073 and rs2227306 gene polymorphisms and the development of glioma.

Several studies have reported the association between polymorphisms in the $I L-8$ gene and the development of different types of cancers, including liver, gastric, lung, ovarian, and colorectal cancers (Burada et al., 2013; Yang et al., 2014; Koensgen et al., 2015; Kumar et al., 2015; Wang et al., 2014, 2015). A previous meta-analysis conducted by Yang et al. (2014) 
indicated that the $I L-8$ rs 4073 gene polymorphism does not influence the susceptibility to oral cancer. In a case-control study comprising 205 patients with hepatocellular carcinoma (HCC) and 208 healthy controls, Wang et al. (2014) discovered no association between the $I L-8$ $-251 \mathrm{~A} / \mathrm{T},+781 \mathrm{C} / \mathrm{T},-353 \mathrm{~A} / \mathrm{T}$, and $+678 \mathrm{~T} / \mathrm{C}$ polymorphisms and risk of $\mathrm{HCC}$ in a Chinese population. Burada et al. (2013), in a case-control study comprising 144 patients and 233 controls, reported that the $I L-8$ rs 4073 polymorphism does not influence the risk of colorectal cancer. On the other hand, another case-control study performed in an Indian population reported that the $I L-8$ rs 4073 gene polymorphism plays an important role in Helicobacter pylori-associated gastric carcinogenesis in northern India (Kumar et al., 2015). Wang et al. (2015) suggested that mutations in the $I L-8$ gene confer an increased risk of lung cancer in Asians. Another study discovered an association between the $I L-8+781$ and +2767 polymorphisms and susceptibility to ovarian cancer in a German population (Koensgen et al., 2015).

A recent study reported that $I L-8$ silencing could suppress the invasion of human glioma U87 cell line (Zhu et al., 2013). Another study revealed that the autocrine function of IL-8 contributes to the invasive phenotype of glioma (Zhang et al., 2015). Only one previous study comprising 300 glioma patients and 300 healthy controls reported an association between the occurrence of the AA genotype at $I L-8$ rs 4073 and increased risk of glioma (Liu et al., 2015). However, there is a lack of evidence confirming the association between the $I L-8$ rs4073 and rs2227306 gene polymorphisms and glioma risk.

In conclusion, we did not observe a statistically significant association between the $I L-8$ rs4073 and rs2227306 polymorphisms and development of glioma in a Chinese population. Further large-scale studies are required to confirm this finding.

\section{Conflicts of interest}

The authors declare no conflict of interest.

\section{ACKNOWLEDGMENTS}

We thanks the great help from staffs in Nanfang Hospital, and these staffs help us to collect blood samples of these patients.

\section{REFERENCES}

Brat DJ, Bellail AC and Van Meir EG (2005). The role of interleukin-8 and its receptors in gliomagenesis and tumoral angiogenesis. Neuro-oncol. 7: 122-133.http://dx.doi.org/10.1215/S1152851704001061

Burada F, Dumitrescu T, Nicoli R, Ciurea ME, et al. (2013). Cytokine promoter polymorphisms and risk of colorectal cancer. Clin. Lab. 59: 773-779.

Cacina C, Pence S, Turan S, Genc F, et al. (2015). Analysis of CASP8 D302H gene variants in patients with primary brain tumors. In Vivo 29: 601-604.

Cui T (2015). CCDC26 rs4295627 polymorphism and glioma risk: a meta-analysis. Int. J. Clin. Exp. Med. 8: 3862-3868.

Jakola AS, Myrmel KS, Kloster R, Torp SH, et al. (2012). Comparison of a strategy favoring early surgical resection vs a strategy favoring watchful waiting in low-grade gliomas. JAMA 308: 1881-1888. http://dx.doi.org/10.1001/ jama.2012.12807

Koensgen D, Bruennert D, Ungureanu S, Sofroni D, et al. (2015). Polymorphism of the IL-8 gene and the risk of ovarian cancer. Cytokine 71: 334-338. http://dx.doi.org/10.1016/j.cyto.2014.07.254

Kumar S, Kumari N, Mittal RD, Mohindra S, et al. (2015). Association between pro-(IL-8) and anti-inflammatory (IL-10) cytokine variants and their serum levels and H. pylori-related gastric carcinogenesis in northern India. Meta Gene 6: 9-16.http://dx.doi.org/10.1016/j.mgene.2015.07.008

Genetics and Molecular Research 15 (3): gmr.15038127 
Li J, Chen Q, Liu B, Yang J, et al. (2015). Association between X-ray repair cross-complementing group 1 gene polymorphisms and glioma risk: a systematic review and meta-analysis based on 22 case-control studies. Int. J. Clin. Exp. Med. 8: 11863-11880.

Lin RP, Yao CY and Ren DX (2015). Association between genetic polymorphisms of PTGS2 and glioma in a Chinese population. Genet. Mol. Res. 14:3142-3148. http://dx.doi.org/10.4238/2015.April.10.25

Liu H, Mao P, Xie C, Xie W, et al. (2015). Association between interleukin 8-251 T/A and +781 C/T polymorphisms and glioma risk. Diagn. Pathol. 10: 138. http://dx.doi.org/10.1186/s13000-015-0378-x

Liu WF, Yu SS, Chen GJ and Li YZ (2006). DNA damage checkpoint, damage repair, and genome stability. Yi Chuan Xue Bao 33: 381-390. http://dx.doi.org/10.1016/S0379-4172(06)60064-4

Lu HW, Huang M, Wang JH, Sun XL, et al. (2015). CCDC26 rs4295627 polymorphism (8q24.21) and glioma risk: a meta-analysis. Genet. Mol. Res. 14: 12074-12084. http://dx.doi.org/10.4238/2015.October.5.20

Mukaida N, Shiroo M and Matsushima K (1989). Genomic structure of the human monocyte-derived neutrophil chemotactic factor IL-8. J. Immunol. 143: 1366-1371.

Ohgaki H and Kleihues P (2005). Epidemiology and etiology of gliomas. Acta Neuropathol. 109: 93-108. http://dx.doi. org/10.1007/s00401-005-0991-y

Schwartzbaum JA, Fisher JL, Aldape KD and Wrensch M (2006). Epidemiology and molecular pathology of glioma. Nat. Clin. Pract. Neurol. 2: 494-503, quiz 1, 516. http://dx.doi.org/10.1038/ncpneuro0289

$\mathrm{Su}$ Y, Qi S, Dou C, Shuang L, et al. (2015). Association of LIG4 and XRCC4 gene polymorphisms with the risk of human glioma in a Chinese population. Int. J. Clin. Exp. Pathol. 8: 2057-2062.

Vieira de Castro J, Gonçalves CS, Costa S, Linhares P, et al. (2015). Impact of TGF-b1 -509C/T and 869T/C polymorphisms on glioma risk and patient prognosis. Tumour Biol. 36: 6525-6532.http://dx.doi.org/10.1007/s13277-015-3343-0

Wang JL, Nong LG, Wei YS, Tang YJ, et al. (2014). Association of interleukin-8 gene polymorphisms with the risk of hepatocellular carcinoma. Mol. Biol. Rep. 41: 1483-1489. http://dx.doi.org/10.1007/s11033-013-2993-5

Wang XB, Li YS, Li J, Han Y, et al. (2015). Interleukin-8 -251A/T gene polymorphism and lung cancer susceptibility: a meta-analysis. J. Cell. Mol. Med. 19: 1218-1222. http://dx.doi.org/10.1111/jcmm.12466

Wen PY and Kesari S (2008). Malignant gliomas in adults. N. Engl. J. Med. 359: 492-507. http://dx.doi.org/10.1056/ NEJMra0708126

Xie K (2001). Interleukin-8 and human cancer biology. Cytokine Growth Factor Rev. 12: 375-391. http://dx.doi. org/10.1016/S1359-6101(01)00016-8

Yang L, Zhu X, Liang X, Ling Z, et al. (2014). Association of IL-8-251A > T polymorphisms with oral cancer risk: evidences from a meta-analysis. Tumour Biol. 35: 9211-9218. http://dx.doi.org/10.1007/s13277-014-2193-5

Zhang B, Shi L, Lu S, Sun X, et al. (2015). Autocrine IL-8 promotes F-actin polymerization and mediate mesenchymal transition via ELMO1-NF-kB-Snail signaling in glioma. Cancer Biol. Ther. 16: 898-911. http://dx.doi.org/10.1080 $\underline{15384047.2015 .1028702}$

Zhu Y, Yang P, Zhang X, Zhang L, et al. (2013). The effect and mechanism of CXCR4 silencing on metastasis suppression of human glioma U87 cell line. Anat. Rec. (Hoboken) 296: 1857-1864.http://dx.doi.org/10.1002/ar.22825

Genetics and Molecular Research 15 (3): gmr.15038127 